\title{
Classification of sub-sectors in creative industry for regional economic development
}

\author{
Deltaningtyas Tri Cahyaningrum ${ }^{1,},{ }^{*}$ Erwin Widodo $^{1}$, and Niniet Indah Arvitrida ${ }^{1}$ \\ ${ }^{1}$ Sepuluh Nopember Institute of Technology, Industrial Engineering Department, 60111 Surabaya, \\ Indonesia
}

\begin{abstract}
Creative industry represents a range of industrial activities that utilize creativity, skills, and personal ability for job creation and economic development of region. A critical step to develop and sustain the competitiveness of the industries is identification process of the sub sectors of the creative industry in a particular country or region. To obtain a better clsassification and region development priorities, this study adopts location quotient (LQ) and ant colony optimization (ACO) approaches, taking Jember as a case in this study. With many indicators, LQ method can classifiy a sector into more than one classification but it describe region demograph. ACO method have an acurate result of classification with many indicators but it doesn't describe the demography of the region. The use of LQ-ACO method can support the government to develop a more feasible classification for the creative industry of sub sector and region priorities.
\end{abstract}

\section{Background}

Creative economy (also known as creative industry) plays an important role in supporting the world economic. The contribution of this sector even has exceedeed the agricultural and industrial sector [1]. As an example, the UK is a country where the economic development is strongly supported by creative industry. In 2016, this sector contributes $34 \%$ of the total the UK's economic value even though average economy only $17.4 \%$ value [2]. This indicates that creative industry has significant high return to the country's economic. This phenomenon also applies in Indonesia. The Indonesian government is currently encouraging theh improvement of productivity of the creative industries continuously. However, Indonesian creative economy currently only contributes $7.05 \%$ of Indonesian total gross domestic product (GDP). This makes Indonesia stay in the $30^{\text {th }}$ position out of 42 countries [3].

Department of Trade Republic of Indonesia defines creative industry as the derivation of the utilization of "creativty, skills and talent of individuals to create wealth and jobs through the creation and utilization of creativity and inventiveness of the individual" [4]. In Indonesia, creative industry is defined in 16 sub sectors, they are: (1) application $\&$ game developer, (2) architecture, (3) interior design, (4) visual communication design, (5)

\footnotetext{
* Corresponding author: deltaningtyas@gmail.com
} 
product design, (6) fashion, (7) film, animation, and video, (8) photography, (9) craft, (10) culinary, (11) music, (12) publishing, (13) art performance, (14) art, (15) television and radio, and (16) advertising.

A suggested way to improve the productivity of the creative industry is by reinforcing the sector using a regional-based approach. Based on European Industries Summit 2015, reinforcement region is an effective means for increasing the contribution of creative industries to economics [5]. With regard to this, identifying the potential subsectors of the creative industry of each region is essential to improve its contribution to the country's economy. An effective approach to perform this identification process is by developing a strategic plan, where in Indonesia it is known as the development plan of creative economic 2025, or "Pengembangan Ekonomi Kreatif Indonesia 2025" [6].

This research is still focused in East Java. This is because the region has a high 2 nd potential development in the creative industry [7]. This paper considers Jember as a case of creative industry classification in East Java. Jember has been regarded as a town that has various expertise in science creativity compared to other towns in Eas Java. This situation corresponds to the who argues that science creativity is an important part in creative industries [8].

Potensial in the sector means the sector have a something spesial. This is like the sector have many company that focus in this sector or much loyalty consumen. All of the sectors not have a same potential. This problem make the sector have to classification into sub potential. Using a sub potential, the sector can desperate into high potential, moderate potential, and low potential.

Identification process of sub potensial in sectors do not only consider creative industry potensial but also potensial in its region. The potensial of the region will be use for select development of the region priority. The identification process cannot use clustering if priority of the region is considerated. So, identification process use classification for this problem.

The purpose of the research is to find classification of sub potential of creative industry sub sector. This research also provides an insight to the government in considering the development plan for sub sectors of creative industry by regarding its sub potential to obtain the region priority. This research employs several indicators that represent financial and industry sectors. The financial indicators involve GDP, investment value, export, the number of labors, and the total number of company. All indicators are used to be the attributes to classify the sub sectors of the creative industries.

For the classification method, this paper introduces the combination of location quotient (LQ) and ant-colony optimization (LQ-ACO) as a classification techniques for the case of creative industry. LQ is used for incorporating the spatial aspect of the industry, while ACO has been known as a popular classification technique. Combining both techniques is proven to be better in resulting more efficient computation time and more consistent outputs in classification.

\section{Methodology, Result and Discussion}

Methodology is describe about a step of classification creative industry and the reason for use LQ-ACO method. The result is describe about outcome, performance, etc in this problem.

\subsection{Methodology}

The literature review that be used for this problem are books, papers, course material and existing database of sub sector creative industry. The method is combination of LQ and 
ACO. This results is classification that categorization into high potential, moderate potential, and low potential. The result of classification will be use to make a development priority of the region. To validation the classification result, this research will be compared with others method, like genetic algorithm (GA) and tabu search (TS).

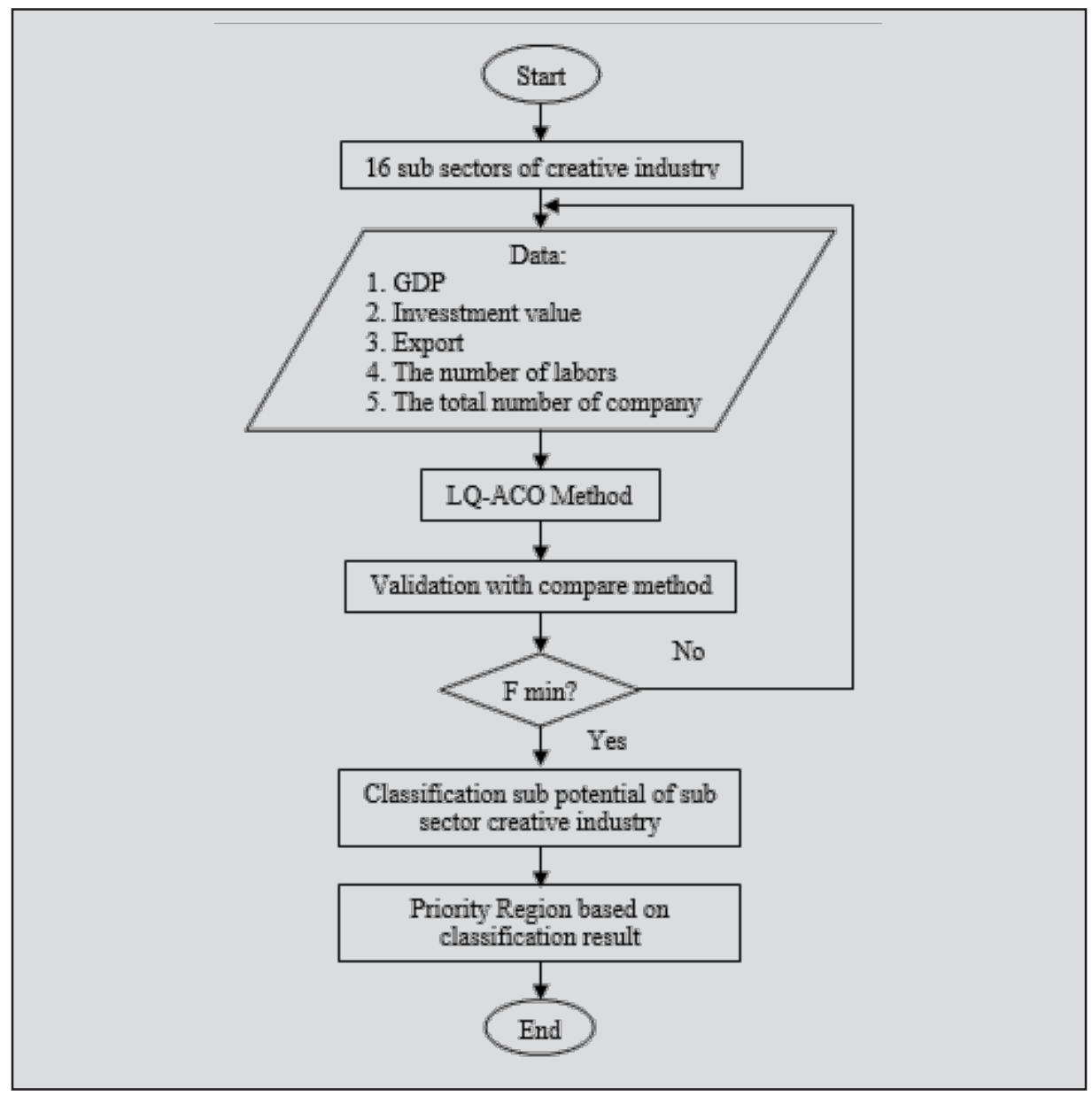

Fig. 1. Methodology of classification of sub sector creative industry.

Based on Figure 1, this research need five data for classification. All data is an attribute for sub sectors of creative industries. Data of sub sector creative industries are GDP, investment value, export, the number of labors, and the total number of company.

Many research use clustering for identification but in this problem the clustering cannot be used. Use clustering, the development of region priority will affect because a region has not a sector that has been clasified into potential sectors. Then, the classification process is used for mapping 16 sectors in creative industry.

To choose a region for priority development, the result of classification is matching with a region based on GDP. When a region has a low GDP, it is matching a moderate potential or high potential of classification. This process is done to obtain the best region for priority development. Jember have 31 region and its GDP. All the region is mapping into low GDP, moderate GDP, and high GDP. Low is GDP $<\mathrm{Rp} 500$ billion, moderate is $\mathrm{Rp} 500$ Billions $<$ GDP $<\mathrm{Rp} 1$ Trillions, high is GDP $>$ Rp 1 Trillions. 


\subsection{Result and Discussion}

Data in this research contains 5 attributes and 16 objects in 2 regions. LQ method use 2 regions for compared in a formula. First region is a Jember city and second region is an East Java. According to EMSI, LQ model [9]:

$$
L Q=\left(l_{\mathrm{i}} / l\right) /\left(L_{i} / L\right)
$$

Where:

$l_{i}=$ amount of indicator of sub sector in specific region

$l=$ amount of indicator in spesific region

$L_{i}=$ amount of indicator of sub sector in region

$L=$ amount of indicator in region

Table 1. The result of LQ with $\mathrm{N}=16$ and $\mathrm{n}=5$.

\begin{tabular}{|c|c|c|c|c|c|c|}
\hline \multirow{3}{*}{$\mathbf{N}$} & \multirow{3}{*}{$\begin{array}{c}\text { Creative Industry of } \\
\text { Sub Sector }\end{array}$} & \multicolumn{5}{|c|}{$\mathbf{n}$} \\
\hline & & 1 & 2 & 3 & 4 & 5 \\
\hline & & GDP & Export & Labor & Investment & Total Company \\
\hline 1 & $\begin{array}{l}\text { Applications\& } \\
\text { Interactive Game }\end{array}$ & 1,095238 & 1,65 & 0,71111 & 1,021739 & 0,77193 \\
\hline 2 & Architecture & 1,642857 & 0,73333 & 0,26667 & 0,817391 & 3,859649 \\
\hline 3 & Interior Design & 0,365079 & 0,55 & 0,64 & 4,086957 & 1,929825 \\
\hline 4 & $\begin{array}{l}\text { Visual Communication } \\
\text { Design }\end{array}$ & 0,547619 & 0,66 & 1,06667 & 2,043478 & 1,28655 \\
\hline 5 & Product Design & 0,438095 & 3,3 & 2,13333 & 1,702899 & 0,192982 \\
\hline 6 & Fashion & 2,190476 & 1,46667 & 1,33333 & 0,204348 & 1,157895 \\
\hline 7 & $\begin{array}{l}\text { Film, Animation, } \\
\text { Video }\end{array}$ & 2,190476 & 1,1 & 0,64 & 0,51087 & 1,28655 \\
\hline 8 & Photography & 3,285714 & 0,22 & 1,06667 & 1,362319 & 0,964912 \\
\hline 9 & Craft & 1,642857 & 1,1 & 1,06667 & 1,021739 & 0,51462 \\
\hline 10 & Culinary & 1,642857 & 1,1 & 1,06667 & 0,681159 & 0,77193 \\
\hline 11 & Music & 1,095238 & 1,83333 & 1,6 & 2,043478 & 0,154386 \\
\hline 12 & Publishing & 1,369048 & 2,2 & 1,06667 & 0,408696 & 0,77193 \\
\hline 13 & Advertising & 0,438095 & 1,1 & 1,06667 & 2,554348 & 0,77193 \\
\hline 14 & Art Performance & 0,219048 & 0,73333 & 2,66667 & 0,766304 & 3,087719 \\
\hline 15 & Art & 1,460317 & 0,66 & 1,06667 & 1,021739 & 0,964912 \\
\hline 16 & Television \& Radio & 1,460317 & 0,55 & 0,53333 & 0,613043 & 3,859649 \\
\hline
\end{tabular}

The result from Table 1 use Eq. (1). While the result of objects LQ $=1$, it can be concluded that object not gives income or outcome in a specific region. While LQ $>1$, the object has impact to specific region with increase income. Then $L Q<1$, the object gives negative impact for specific region with decrease income or increase outcome.

From Table 1, object 1 gives a positive impact to Jember city in GDP, export, and investment indicator. Whereas, labor and total company or business give a negative impact. Consequently, when amount of investment in creative industry of sub sector increase, it will gives an income of the Jember increase too.

According to LQ's result, ACO method is used with $\mathrm{n}$ attributes, $\mathrm{K}$ classification, $\mathrm{N}$ object, R ant and 10 replications. The objective function of ACO is defined with Euclidean distance. This object function uses mathematical formulation from Shelokar (2004) that can be described as

$$
\operatorname{Min} F(w, m)=\Sigma_{K, j=1} \Sigma_{N, i=1} \Sigma_{n, v=1} w_{i, j}\left\|x_{i, v}-m_{j, v}\right\|^{2}
$$




$$
\begin{gathered}
\sum_{k, j=1} w_{i, j}=1, i=1, \ldots, N \\
\sum_{N, i=1} w_{i, j} \geq 1, j=1, \ldots, K
\end{gathered}
$$

Where $x_{i, v}$ is a atribut value $v$ from sample $i ; m$ is a classification center from matrix size $\mathrm{K} \mathrm{x} \mathrm{n} ; m_{j, v}$ is an average of atribute value $v$ to all classification $j ; w$ is a weight matrix size $\mathrm{N}$ $\mathrm{x} \mathrm{K} ; w_{i, j}$ is a weight of object $x_{i}$ with classification $j$ that assigned as

$$
w_{i, j}=\left\{\begin{array}{l}
1, \text { if object } i \text { is a class } j \\
0, \text { other }
\end{array}\right.
$$

The result of classification is showed in Tabel 2. This tabel is a classification result in 9 replications. The average of $\mathrm{F}$ value is 2141.656032 with $\mathrm{F}$ best is 1406.566364 and $\mathrm{F}$

\begin{tabular}{|c|c|c|c|c|c|c|c|c|c|c|c|c|c|c|c|c|c|}
\hline & \multirow{2}{*}{ Min F } & \\
\hline & & 1 & 2 & 3 & 4 & 5 & 6 & 7 & 8 & 9 & 10 & 11 & 12 & 13 & 14 & 15 & 16 \\
\hline S1 & 1406,566364 & 3 & 3 & 1 & 3 & 3 & 1 & 3 & 3 & 2 & 2 & 1 & 1 & 3 & 1 & 1 & 1 \\
\hline $\mathrm{S} 2$ & 1982,099662 & 2 & 3 & 2 & 3 & 3 & 1 & 1 & 1 & 3 & 1 & 1 & 2 & 2 & 3 & 1 & 3 \\
\hline S3 & 2033,898816 & 3 & 3 & 1 & 3 & 1 & 3 & 2 & 3 & 1 & 2 & 1 & 1 & 1 & 3 & 1 & 1 \\
\hline $\mathrm{S} 4$ & 1953,14353 & 1 & 1 & 1 & 1 & 1 & 3 & 2 & 1 & 3 & 3 & 3 & 3 & 2 & 3 & 3 & 2 \\
\hline S5 & 1862,982572 & 2 & 3 & 3 & 1 & 2 & 3 & 1 & 2 & 3 & 2 & 3 & 1 & 2 & 3 & 1 & 1 \\
\hline S6 & 1794,022393 & 1 & 1 & 1 & 3 & 2 & 3 & 1 & 3 & 3 & 3 & 2 & 3 & 2 & 2 & 3 & 3 \\
\hline S7 & 1901,722589 & 2 & $J$ & 2 & 1 & 2 & 2 & 3 & 2 & $J$ & 2 & 3 & 3 & 2 & 1 & 1 & 2 \\
\hline S8 & 1940,508594 & 1 & 1 & 2 & 1 & 3 & 1 & 3 & 3 & 1 & 2 & 1 & 3 & 2 & 1 & 2 & 2 \\
\hline S9 & 1822,45576 & 2 & 1 & 3 & 1 & 3 & 1 & 2 & 1 & 1 & 1 & 1 & 2 & 3 & 1 & 3 & 3 \\
\hline $\mathrm{S} 10$ & 2047,845196 & 1 & 3 & 1 & 2 & 1 & 1 & 3 & 3 & 2 & 3 & 2 & 2 & 3 & 2 & 2 & 2 \\
\hline
\end{tabular}
worst is 3199.022401 .

Table 2. The result of LQ-ACO method with 10 replication.

To evaluate the performance of LQ-ACO Method, we have compared it with several method including genetic algorithm (GA) and tabu search (TS) [10]. Each experiment will

\begin{tabular}{|c|c|c|c|c|c|}
\hline \multirow{2}{*}{ Method } & \multicolumn{3}{|c|}{ Function value } & \multirow{2}{*}{$\begin{array}{l}\text { Function } \\
\text { evaluation }\end{array}$} & \multirow{2}{*}{ CPU time (s } \\
\hline & $F_{\text {best }}$ & $F_{\text {avg }}$ & $\mathrm{F}_{\text {worst }}$ & & \\
\hline LQ-ACO & 1406.566364 & 2141.656032 & 3199.022401 & 1000 & 0.52 \\
\hline LQ-GA & 1413.577643 & 2146.558306 & 3211.276701 & 2503 & 1.43 \\
\hline LQ-TS & 1413.246732 & 2142.864511 & 3203.177685 & 1508 & 0.85 \\
\hline
\end{tabular}
be performed 10 replications and will be showed in Table 3 .

Table 3. The result of $L Q$ with $N=16$ and $n=5$.

For classification of creative industry, the LQ-ACO approach is the best method because it has minimum optimum value is 1406.566364 and fast compute time less than 1 second.

From Table 2, 7 sectors is classified low potential sectors, 2 sectors is classified into moderate potential, and 7 sectors is classified into high potential. This result will be matching into a region that has been mapping. 
Be exampled Sukorambi have low GDP. Sukorambi is matched into high potential sector, like culiner. Culiner is chosen because it is a sub sectors in Sukorambi. Another sub sector are not chosen because Sukorambi have not that sub sectors. Sukorambi's GDP is Rp 102 Billion and when it is matching with culiner, the prediction GDP is Rp 1.7 Millions. The prediction GDP of Sukorambi increasly because Sukorambi have 28 company that focused in this sector. This prediction consider a mount of labor and salary of labor like an atribute are used for calssification.

\section{Conclusion}

The suggestion of current research is that LQ-ACO method is the best algorithm for performing classification of sub sectors in creative industry into sub potential classification because a creative industry of sub sectors only can be classified in one classification. In addition by matching a region and a sub potential of creative-industry sub-sectors provides a priority for undertaking development in a particular region.

Like Sukorambi, this region has been changing to be a high GDP when it is matched with a high potential sub sectors such as culinary and television $\&$ radio. Itchanges a low GDP's region and moderate GDP's region and increase an actual GDP Because of that, a government can choose the region for the development priority from the increase.

For our future research, to simplify research process, case study used region that have creative industry department to obtain the available data, like a company of creaetive industry sub sectors. This research is long time in take a data.

This research is addresed to Departement of Industrial Engineering, Faculty of Industrial Technology of Sepuluh Nopember Institute of Technology.

\section{References}

1. F. Afiff, Pillars of Creative Economy (Binus University, Jakarta, 2012)

2. DCMS, The UK Creative Industries (The Creative Industries, in press, 2016)

3. R. Salahuddin, Economic Based on Creativity and Innovation (Coordinating Minister for the Economy Republic of Indonesia, in press, 2015)

4. S. Wiryono, H. Susatyo, S. Utomo, Risk Mapping on Dynamics Creative Industry, 169 (2014)

5. N. Bocella, I. Salerno, Creative Economy, Cultural Industries and Local Development, 223 (2016)

6. M. Pangestu, Creative Economy of Indonesia 2025 (unpublished)

7. Midd, Jember have a potential Creative Industry (Gempur, Jember, 2016)

8. Suryana, Creative Economy New Economy: Changing Idea and Creating Probability, (Salemba Empat, Jakarta, 2013)

9. R. Sentz, Understanding Location Quotient (EMSI Data Works, 2011)

10. P. Shelokar, V. Jayaraman, B. Kulkarni, AACAC 509 (2004) 